\title{
Effective Information Provision as a Panacea for The Resolution Of Conflict In Autonomous Communities: A Case Study Of Amiyi Akah Community
}

\section{BY}

UMUNNAKWE, G. C.

\begin{abstract}
The paper studied the Amiyi Akah Community, a village in Umuaka Autonomous Community in Njaba Local Government area of Imo State, Nigeria. The paper adopted a survey method and used questionnaire complemented with unstructured interviews and observation to elicit the desired responses. In all, the target population was $10 \%$ of the entire population. Since it runs in thousands only 1480 were used. Data collected were analyzed using tables and graphic representations. In conclusion, it was observed that autonomous community creation is a welcome venture if the government would strictly stipulate guideline be used in Ezeship election of which has been the major source of conflict. Communities should work towards establishing rural libraries and information centres to help in keeping the populace educated and informed on the on-goings in the society.
\end{abstract}

Keywords: Information provision, conflict resolution autonomous communities, Amiyi Akah Community.

\section{Introduction:}

Information is an effective resource that can liberate man from the shackles of ignorance, disease and poverty. Information is needed at every point in time for various purposes and effective guard to life. Information cannot rightly be pinned down to a single definition. Information according to Afolabi(2003) is a conveyor, a change agent, a reinforcement of ideas and opinions. This entails that information if well managed would be a resource that could generate a positive or negative change. Ajibero(1993) defined information as data of value in planning, decision making and evaluation of programmes. Okee(2005) regarded information as data or symbols which can be physically recognized and processed either by human or machine. Information is a renewable resource, it is not depleted once applied, but remains available for further use elsewhere. Supporting the above views on information Ifedon and Ahiauzu(2006) saw information as a structured data that causes a human mind to change its opinion about the current state of the real world and contributions to a reduction in the uncertainty of the state of the system. Ifidon(2002) therefore concluded that information is a priority for development of any group of people.

The provision of this information is therefore a panacea for achieving lot of projects, resolving issues in different aspects of life endeavour and proper handling of issues. Information provision therefore is a very sensitive issue that need not be neglected. Information provision by definition is the availability of information sources, materials and needs for use by information seekers. Information provision and utilization is a tool for development, when information is provided a target goal will be achieved. The provision of information turns out to be one of the simplest way of resolving issues, clearing facts and maintaining good and stable relationships.

Conflicts are bound to occur as long as there is human existence. Man as a controversial being cannot stay without conflicts. Conflict therefore is an intrinsic and intentable aspect of human existence and cuts across all aspects of human life. Conflict is a state of disagreement between people, groups and countries. It is not a new phenomenon but rather it is a problem that has grown with time. Francis (2007) defined conflict is a pursuit of incompatible interest and goals by different groups. This entails that there is no harmony as far as conflict is concerned. Asobi(2004) described it as the product of a number of contradicitions which might be as a result of clash between tradition and modernity, tension between cartographical fact and cultural reality difference regarding responsibilities and their likes (www.answer,2009 ). Apart from what has been said easiler, Ifidon (2007) also identified some of the causes of conflict as indigene - setter syndrome, unemployment and poverty, marginalization process of the creation of foci of power allocation, rise of ethnic militants, boundary and land dispute as well as conflict over value. Conflicts therefore are of different types among which are community conflict, diplomatic, economic, emotional environmental, resource conflict, external conflict, ideological 
relationship conflict, racial conflict, international interpersonal, intra-societal, military, religious based conflict, workplace conflict, data conflict to mention but these few(www.answer.2009)

On the other hand Oyeshola (2005) identified two major types and sources of conflicts to include global and armed conflicts. Owens-Ibie(2000) also identified condition that may lead to conflict as incompatible goals, unrealistic expectations, differing rates of relational growth, inaccurate perceptions and attributions and cultural differences. Conflict as a concept helps to explain many aspects of social life such as social disagreement, conflicts of interests and frights between individuals groups and organizations. It is a negative experience and can be harmful to human life.

\section{Causes of Conflicts}

Conflicts can be as a result of a clash of interest, values, actions or directions not properly addressed. It might also result when the redirection of one motivating stimulus involves an increase in another, so that a new adjustment is demanded. Equally it might be a national disagreement resulting from individuals or groups that differ in beliefs, attitudes, values or needs. It can also originate from past rivalries and personality value differences, goal differences, methodology difference, standard performance, lack of co-operation, difference regarding authority and competition over resources, non compliance with rules and regulation. The conflict in question is community conflict which resulted from the verge of creation of autonomous community. A community as defined by Webster's Encyclopedia Dictionary (1992) is a body of people living near one another and in social relationship. Iloeje, Ogieriaikhi and Malu(1993) defined it as the territorial area where a group of people live. A rural community is a typical local community setting that shades land to a growing urban community closely. It grows food which it sends to the urban areas for consumption. Most of the local community members engage themselves in farming, trading, carpentry, hunting, drumming, bricklaying, laundry, blacksmithing, bicycle repair and local politics. The members though in the rural setting, make efforts to develop their communities through community personal efforts with little or no government support.

Community development according to www.answer.com (2009) is the active involvement of people in the issue of which affects their interest in the local environment. It is developing the powers, skills, knowledge and experiences of people as individuals and in groups, thus enabling them to fully participate in a truly democratic process. The rural communities in one way or the other face different hazards especially conflicts on various issues arising from their rural communities. These conflicts go a long way to hamper rural community development as can be seen the case of Umuaka town with particular reference to Amiyi Akah village. This study is on the effects of information provision as a panacea for the resolution of conflict in autonomous communities.

Autonomous community by definition is a group of people inhabiting an identifiable geographical area comprising of people bound by a traditional and cultural way of life with a common historical heritage recognized and approved by the government. It is an independent self governing community subject only to its own laws and from the government. It gained official currency after Nigerian Independence and has become a new addition to the lexicon of Nigerian political scene and history. The local government reforms of 1976 Dauski report brought the issue of autonomous community into a clear and acceptable views.

The relevance of these autonomous communities cannot be over emphasized. It helps in raising political social and economic status of a community. It is regarded as an innocuous sort of home rule that has become crucial for Nigeria political, economic and social development. With the constitutional creation of local government as the third tier of government, the political relevance of the Igbo autonomous community is further enhanced. It has become the beginning of an individual political career and therefore more than in the colonial period a veritable nursery of political education. It plays a supportive role to the local government, state and federal government in the provision of educational and social facilities, pipe borne water, rural electrification, motor parks, markets, bridge, postal facilities, roads, civic centres to mention but a few. It equally helps to acknowledge the self help efforts of its development and improvement of town unions and abroad.

* The issue of conflicts cannot be overlooked as far as these autonomous communities are concerned, and that is the reason for looking into conflict resolution in autonomous community. Conflict resolution is the way of firmly deciding to resolve what ever issue that have resulted to a conflicts. Every problem has an expiring date and therefore to resolve the issue Adewiyi(2009) specified four problem solving process which 
involves identification of the problem, generation of alternative solutions, select solution to the problem and finally implement and evaluate the solution. Owens-Ibie(2000) also identified his own resolution strategy as collaboration, negotiation, meditation and arbitration. These method can be workable if really implemented.

Information is needed at each point in time for the resolution of the conflict. The provision of these information with reliable resources becomes imperative for effective resolution. Libraries the key root to information cannot be left out including other information centres.

The major issue of conflict within this community is the location of sovereignty, who takes the lead in the Ezeship. This has become a very contentious issue and has cut across the entire Umuaka town where the autonomy has first existed before the Amiyi Akah cade/autonomy.

\section{The Study Setting}

Amiyi Umuaka is among one of the ten villages that made up the old Akah town in Njaba local government area of Imo State. Amiyi is the most densely populated village in Umuaka town with a population of one million. It occupied the third position in the old Akah town in Njaba local government area of Imo State. Amiyi has (14) fourteen kindreds with a paramount chief and supported with the kindred leaders as was elected from each representatives ward whose duties are to oversee the activities of the people and report to the paramount chief. Amiyi village was among the first three villages to establish a unity primary school in their locality and granted scholarship to less privileged pupils. They are predominately Catholics and were the first to have a parish, first to produce an indigenous priest and numerous number of graduates who have made their mark in teaching, engineering, medical lives, law and other professions.

Majority of the citizens are farmers while others engage in trading, local craft and other economic activities. As a community development conscious people, they have built community halls, graded and maintained rural roads, community water schemes as well as scholarships to their wards to mention but these few.

Amiyi community has been known for peace and unity until March, 2007 when the relative peace and tranquility was disrupted with chaos, tension and rancor resulting to conflict of different types because of the issue of autonomous community creation. The Ezeship tussle has caused a lot of friction which led to killings and destruction of lives and property.

\section{Purpose of the Study}

1. To find out if there is any conflict in the community

2. To find out the causes of the conflict

3. To find if the conflict have been resolved

4. To examine the impact of the conflict in the community development projects

5. To proffer suggestions on how to resolve the conflicts.

\section{Research Methods}

The study was carried out with a descriptive survey method. The data collection method was with constructed questionnaires and oral interview to elicit the desired answers. The population for the study included selected category of people from the community such as the paramount chiefs, kindred heads, elder statement, political leaders representative and youths. Only $10 \%$ of the population were sampled which corroborates the views of Nwana (1997) which states that if the population runs in thousands only $10 \%$ of the entire population size will be used as sample. 
Results and Discussion of Finding

Table 1: Background information of respondents biodata

\begin{tabular}{|c|c|c|c|c|}
\hline 1. & Gender/sex & Frequency & \multicolumn{2}{|c|}{ Percentage } \\
\hline a. & Male & 1128 & \multicolumn{2}{|c|}{$76.2 \%$} \\
\hline b. & Female & 352 & \multicolumn{2}{|l|}{$23.8 \%$} \\
\hline & Total & 1480 & \multicolumn{2}{|l|}{$100 \%$} \\
\hline 2 & Age & Frequency & \multicolumn{2}{|c|}{ Percentage } \\
\hline a. & Below 35 & 204 & \multicolumn{2}{|c|}{$13.78 \%$} \\
\hline b. & $36-45$ & 547 & \multicolumn{2}{|c|}{$36.96 \%$} \\
\hline c. & $46-55$ & 339 & \multicolumn{2}{|c|}{$22.91 \%$} \\
\hline d. & $56-65$ & 209 & \multicolumn{2}{|c|}{$14.21 \%$} \\
\hline e. & $66-75$ & 137 & \multicolumn{2}{|c|}{$9.25 \%$} \\
\hline f. & $76-85$ & 35 & \multicolumn{2}{|l|}{$2.36 \%$} \\
\hline g. & 86 and above & 9 & \multicolumn{2}{|l|}{$0.16 \%$} \\
\hline & Total & 1480 & \multicolumn{2}{|l|}{$100 \%$} \\
\hline 3. & Educational qualification & Population & \multicolumn{2}{|c|}{ Percentage } \\
\hline a. & No formal education & 415 & \multicolumn{2}{|c|}{$28.04 \%$} \\
\hline b. & FLSC - WASC & 823 & \multicolumn{2}{|c|}{$55.61 \%$} \\
\hline c. & OND - HND & 99 & \multicolumn{2}{|c|}{$6.61 \%$} \\
\hline d. & BSC - MSC & 136 & \multicolumn{2}{|l|}{$9.19 \%$} \\
\hline e. & PhD and above & 7 & \multicolumn{2}{|l|}{$0.47 \%$} \\
\hline & Total & 1480 & \multicolumn{2}{|l|}{$100 \%$} \\
\hline 4 & Position/status & Population & Male & Female \\
\hline a. & Paramount chief & 1 & 1 & - \\
\hline b. & Eze elect & 1 & 1 & - \\
\hline C. & Kindred heads & 14 & 14 & - \\
\hline d. & Elder statement & 820 & 664 & 156 \\
\hline e. & Youth members & 600 & 420 & 180 \\
\hline \multirow[t]{2}{*}{ f. } & Political leader/representatives & 44 & 28 & 16 \\
\hline & Total & 1480 & 1128 & 352 \\
\hline 5. & Occupation & Population & \multicolumn{2}{|c|}{ Percentage } \\
\hline a. & Teaching & 280 & \multicolumn{2}{|c|}{$16.89 \%$} \\
\hline b. & Trading & 393 & \multicolumn{2}{|c|}{$26.55 \%$} \\
\hline C. & Local craft & 72 & \multicolumn{2}{|c|}{$4.86 \%$} \\
\hline d. & Herbalist & 8 & \multicolumn{2}{|c|}{$0.54 \%$} \\
\hline e. & Farming & 477 & \multicolumn{2}{|c|}{$32.23 \%$} \\
\hline f. & Retired civil servant & 260 & \multicolumn{2}{|c|}{$13.51 \%$} \\
\hline g. & Other professional & 80 & $5.41 \%$ & \\
\hline & Total & 1480 & $100 \%$ & \\
\hline
\end{tabular}

\begin{tabular}{|l|l|l|l|}
\hline 6. & Marital status & Population & Percentage \\
\hline a. & Married & 540 & $36.89 \%$ \\
\hline b. & Single & 600 & $40.54 \%$ \\
\hline c. & Divorced & 47 & $3.18 \%$ \\
\hline d. & Widow & 287 & $18.39 \%$ \\
\hline & Total & $\mathbf{1 4 8 0}$ & $\mathbf{1 0 0 \%}$ \\
\hline
\end{tabular}

Table 1 above presents the background information of respondents on gender, age, educational qualification, position/status, occupation and marital status. Data collected shows that (1128) $76.2 \%$ were male while (352) $23.8 \%$ represents the women folk. The highest age representation were below 36-45 years which was (36.96\%) followed by 46 - 55 with (22.91\%) while the lowest were $76-85$ years with (2.36\%) and 86 and above $(0.16 \%)$ respectively. Their education qualification show that $55.61 \%$ had first school leaving certificate - West Africa School Certificate (FSLC - WASC). Those with no formal 
education were $6.69 \%$, OND-HND $28.04 \%$ while $9.19 \%$ and $0.47 \%$ respectively represents the highest educational qualification. There was a fair representation of the group in the community ranging from the paramount chief, to the Eze Elect, political leaders/representatives, kindred heads, elder statement and youth members selected randomly from the different kindreds.
Majority of the respondents were farmers which represented $32.23 \%$, traders and teachers represented $26.55 \%$ and $16.89 \%$ respectively while the least, herbalist represented $0.54 \%$. On marital status $40.54 \%$ were married, $36.49 \%$ were single, $19.39 \%$ were widows while divorces were $3.18 \%$.

Table 2: Existence of Conflict

\begin{tabular}{|l|l|l|l|}
\hline S/N & Types of conflict that existed & Frequency & Percentage \\
\hline a. & Tribal wars & 5 & $0.34 \%$ \\
\hline b. & Massive fighting & 254 & $17.16 \%$ \\
\hline c. & Political unrest & 329 & $22.23 \%$ \\
\hline d. & Religious clash/violence & 11 & $0.74 \%$ \\
\hline e. & Rioting & 193 & $13.04 \%$ \\
\hline f. & School cult/rioting & 9 & $0.16 \%$ \\
\hline g. & Intra personal conflicts & 86 & $5.89 \%$ \\
\hline h. & Racial conflict & 17 & $1.15 \%$ \\
\hline i. & Ezeship/leadership tussle & 595 & $40.20 \%$ \\
\hline & Total & $\mathbf{1 4 8 0}$ & $\mathbf{1 0 0 \%}$ \\
\hline
\end{tabular}

Data on table 2 revealed that there is conflict in the community. With the different representations on the table as expressed it show that they had different opinion on the reasons for the conflict but the majority opinion was on Ezeship/leadership tussle which recorded $40.20 \%$. also personal interview and interaction with Ahamaraze one of the elder statesman and kindred leader collaborated the responses elicited, Ezeship/leadership tussle being the major reason for the conflict.

\section{Table 3: Cause of Conflict}

\begin{tabular}{|l|l|l|l|}
\hline S/N & Causes of Conflict & Frequency & Percentage \\
\hline a. & Border dispute & 19 & $1.28 \%$ \\
\hline b. & Engagement in struggle over values \& claims & 48 & $3.24 \%$ \\
\hline c. & struggle for power \& Ezeship position & 650 & $43.91 \%$ \\
\hline d. & Struggle for autonomy \$ separation & 357 & $24.12 \%$ \\
\hline e. & Struggle for political position \& recognition & 230 & $15.54 \%$ \\
\hline f. & Reaction against injustice & 110 & $7.43 \%$ \\
\hline g. & Abuses of human rights and undue privileges & 24 & $1.62 \%$ \\
\hline h. & Reaction against unfavourable government policies & 36 & $2.43 \%$ \\
\hline i. & Gender/crimination & 6 & $0.40 \%$ \\
\hline & Total & $\mathbf{1 4 8 0}$ & $\mathbf{1 0 0} \%$ \\
\hline
\end{tabular}

Table 3 shows details of data collected on the causes of conflict. As reflected in the data, the struggle for power and Ezeship rated 43.91\% followed by struggle for autonomy and separation, 24.12\% and the struggle for political position and recognition with $15.54 \%$ rated highest as causative factor for conflict. Other opinion were minor and rated very low with $0.40 \%$ gender discrimination which recorded $0.40 \%$ and the least. 
Table 4: Ways of resolving conflicts

\begin{tabular}{|l|l|l|l|}
\hline S/N & Ways of resolving conflicts & Frequency & Percentage \\
\hline a. & Community efforts the on peaceful negotiation & 301 & $20.34 \%$ \\
\hline b. & Church appeal and prayers & 271 & $18.31 \%$ \\
\hline c. & Total neglect and abandonment & 0 & $0.00 \%$ \\
\hline d. & Paying compensation to affected families & 102 & $6.89 \%$ \\
\hline e. & Continued dialogue among stakeholders & 497 & $33.38 \%$ \\
\hline f. & Government intervention & 186 & $12.57 \%$ \\
\hline g. & Using force on the community by police and army & 123 & $8.31 \%$ \\
\hline & Total & $\mathbf{1 4 8 0}$ & $\mathbf{1 0 0 \%}$ \\
\hline
\end{tabular}

The representation shows that majority of the target population accepted that conflict would be resolved with continued dialogue with stakeholders, the rated $33.58 \%$. Furthermore community effort on peaceful negotiation rated $20.34 \%$ while total neglect and abandonment was not accepted by any group. Prayers and appeal by religious leaders were also recognized as a way out because as the peaceful negotiation and dialogue were going on women occasionally booked masses, offered prayers at their different ward levels for God's intervention. All accepted there was no total negligence as far as the conflict resolution was concerned. There is no significant impact on the interference of the government, police and military personnel's.

\section{Out Come of the Conflict}

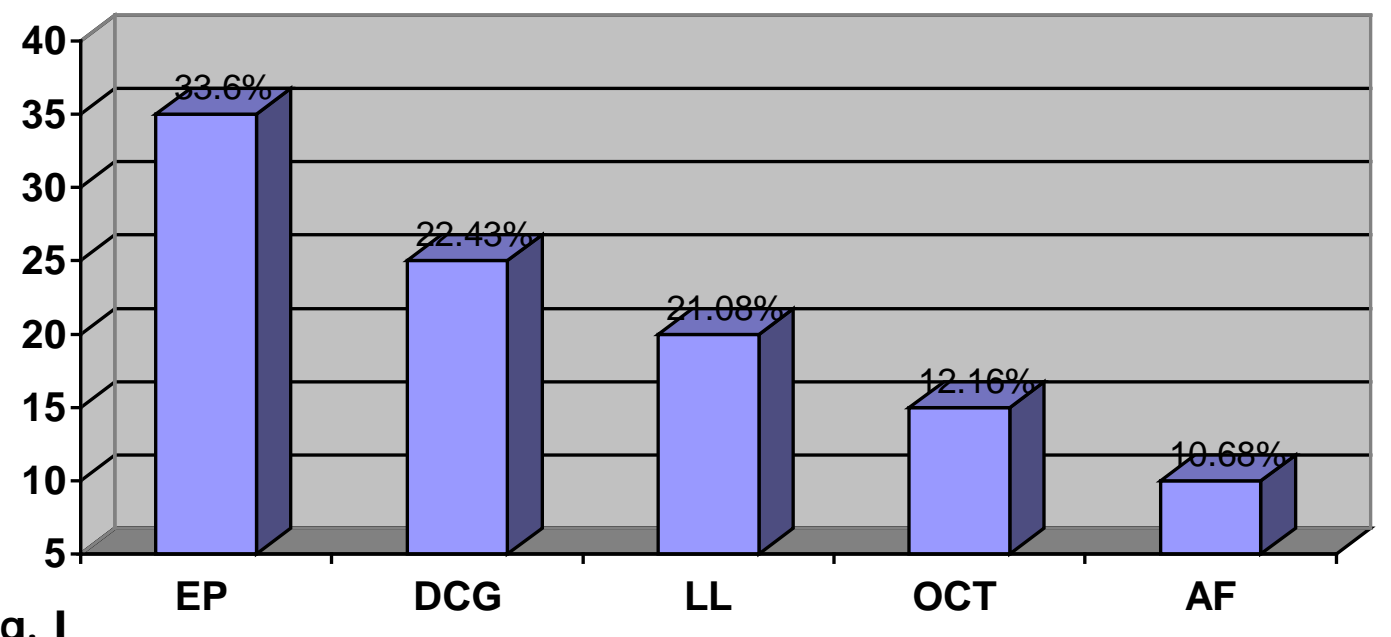

Fig. I

Responses on the outcome of the conflict

Key: $\quad \mathrm{EP}=$ Enenity to the highest peak

DCG $=$ Disruption of community development activities

LL = Lost of lives and property

OCT $=$ Disorder, confusion and tension

$\mathrm{AF}=$ Anger, frustration, fear pains and humulation

The fig. I statistics on outcome of conflict has the following responses as presented. Enemity was rated the highest of the conflict out come with $33.6 \%$ following by disruption of community development activities 22.43\%. 21.08\% for loss of property, $12.16 \%$ was for disorder, confusion and tension, while $10.68 \%$ anger frustration, pains and humiliation rate low as a resultant effect of conflict.
This corresponds the adage which says united we stand but divided we fall. Lack of unity does not give people opportunity of being together, planning together for enhanced development. 


\section{Discussion of Finding}

Results of the investigation and interviews conducted coupled with personal observation indicated that there is conflict which was as result of struggle for Ezeship position and struggle for autonomy and separation which rated the highest. Other minor causes also observed were struggle for political position and recognition, reaction against injustice, engagement in struggle over values and claims, reaction against unfavourable government policies, abuse of human rights and undue privillages, border dispute and gender discrimination. It was discovered that Amiyi Akah had been the most peaceful village until the issue of the autonomy which truncated the community's peace and harmony. The wind of conflict blowing across Akah community has eventually engulfed Amiyi Akah known for its usual peace and rural development activities, academic excellence and achievement.

This has now resulted to tension, lack of confidence, insecurity of lives and property, disorder, confusion enemity of the highest level, anger, frustration, fear, pains and humiliation. The issue of creation of autonomous community has created a lot of problems in different communities, especially in the area of study. Investigations made in other old Akah towns revealed that non of the communities has ever remained peaceful and united since the advent of autonomous communities saga. In the time past the following villages under the old Akah town experienced conflicts; Amazano in 1996, Ibele in 2004, Amakor and Obakwu 2005. However the climax was that of Amiyi which claimed more lives, properties and resulted to people running away from their homes for safety.

The grassroot development and its benefit which is a major dividends of autonomy has seized to exist. Greed, quest for leadership and accumulation of wealth have become the order of the day resulting to Ezeship tussle with conflict of different kinds arising. It is now a curse on communities instead of a blessing of new development, new interests and desires now devastating conflicts. The effect on Amiyi Akah community is yet unimaginable and yet to be resolved.

From the study, it was discovered that information provision was not properly addressed. The inhabitants lacked adequate information provision to tackle their problems. They based their information on rumours there was no rural library or any reliable media for local to help in effective information provision for the inhabitants.

\section{Recommendations}

Unity brings love, progress, development and peace but where there is no unity there is no progress. Our society has not fully grown to embrace autonomous community.

The autonomous community should be regarded as innocuous sort of home rule that will help in the political, social and economic development of the communities. In this case self-help efforts of development and other unions both at home and in the Diaspora play a supportive roles to the local state and federal governments in the provision of educational and social facilities. The government should take a firm stand either to ban the creation of autonomous communities since it has outgrown its usefulness. If the government cannot effectively handle and co-ordinate its activities, it is useless to go into ventures that will destroy the communities instead of the progress so desired.

There should be proper orientation at the grassroots level to achieve the good goal of autonomous community creation. Efforts should be made towards discouraging Ezeship struggle, greed and avarice. Since conflicts are natural, one of the best methods to settle community disputes should be by negotiation until mutually acceptable solution is arrived at. There must be a mutual respect at all level and all times to engender peace and unity.

All communities should help aid the provision of effective information sources and materials that will help in conflict resolution. Rural communities should therefore provide services which enable them have timely access to information which will liberate them from the shackles of ignorance, disease and hunger.

In all honesty, effective information provision should be a panacea for the resolution of conflict in autonomous community. This is because right and adequate information if provided will solve and resolve most of the issues prevalent in autonomous communities

\section{References}

Adewuji, O. W. (2009). The library as a tool for conflict resolution: the Nigerian perspective. Paper presented at the $47^{\text {th }}$ National Conference and Annual General Meeting of NLA. 53 - 60.

Afolabi, A. K. (2003). Information needs, information sources and information seeking behaviour of commercial vehicle drivers in Ondo State. Gateway Library Journal 6(2): 89 - 7. 
Ahiauzu, B. (2006). The impact of professional information flow in National Development: the case of the Association of Women Librarian in Nigeria. Paper presented to the Association of Women Librarians in Nigeria(AWLA) at the NLA Annual Conference and AGM Akure $20^{\text {th }}$ $25^{\text {th }}, 1-18$.

Ajibero, M. I. (1993) Librarianship: the mother of all profession. Paper presented at the 1999 NLA Annual Conference and AGM $8^{\text {th }}-14^{\text {th }}$ May 13.

Asobie, A. (2004) Conflict resolution and human right: a case study approach Academic Staff Union of Universities (ASUU). Educational Publication Service E-watch Print Media Ashowo UI Ibadan.

Francisc, D. J. (2007) Peace and conflict studies an African Overview of basic concepts. In S.C. Best Ed. Introduction to Peace and conflict studies in West Africa: A reader, Ibadan - Spectrum Books.

Ifidon, S. E. (2002) Information underdevelopment and conflict prevention in Niger Delta. A paper presented at the National Conference on Management of Petroleum and Engergy Resources for suitable Development in the Niger - Delta in the $21^{\text {st }}$ Century organized by the Department of Economics, Delta State
University, Abraka - Nigeria between $7^{\text {th }}-9^{\text {th }}$ September.

Iloeje, N. P.; Ogieriaikhi, I. O. and Malu, O. B. (1993). Junior secondary social studies book 3. Enugu: Insdberg Nigeria Limited.

Kilman, Thomas (2009) www.answer.com Available and accessed from the net $12^{\text {th }}$ Nov. 2009.

New Lexicon Webster's Encyclopedic Dictionary of the English Language (1992) Publications, Inc.

Nwana, O. C. (1992) Introduction to educational research. Ibadan: Heinnan Educational Books.

Okoro, Okee (2005) Information explosion and the role of information resources management in the new millennium. Computerizing of library operations the information age. Proceedings of selected papers of the cataloguing, classification and indexing section of the Nigeria Library Association Cataloguing, Classification and Indexing section of the Nigerian Library Association Cataloguing, Classification and Indexing section 2001 - 2002. 59-65.

Owens-Ibie, N. (2000) "Conflict in organization" organization communication: A book of readings edited by E.O. Soola-Ibadan: Delby Concepts 74 $-85$.

Oyeshola, Dokun(2005) Conflict and context of conflict resolution. Ile-Ife. Obafemi Awolowu University Press Limited 105-117. 